\title{
PREFACE: BETWEEN WORLDS
}

\begin{abstract}
When hen Americans or Cambodians ask me, "Where are you from?" or "What nationality are you?" their insistent curiosity is demanding, like an interrogation, a test of loyalty. My answers are prefaced with hesitation perhaps because I want the best answer but I'm unsure what it is.

This book is an attempt at a complete answer. My truth is difficult. You see, I don't feel entirely Cambodian or completely American. Cambodia is my birthplace, with the Khmer culture always deep in my psyche, but America is my home and my life. How do I give a simple answer to these questions?

My children are luckier. As they go through daycare, schools, neighborhoods, friendships, and jobs, they'll hear those questions but they know they are Americans; they won't be stumped. Otherwise, I hope this book will help them or, at least, remind their generation that some things must not, should not, be forgotten.

I'm into my twenty-fourth year as a professional landscape architect for the USDA Forest Service. In 1988, the University of Oregon granted me a degree in landscape architecture focusing on environmental planning and design. I spent most of my career in Bend, Oregon. Today my family and I live in Greenfield, Wisconsin, in a two-story wooden house with a porch in front. Programmable water sprinklers water the little garden and the yard in front. The kitchen countertops are made of marble. The stainless steel sinks have hot and cold water and a switch chops up garbage. The living room is filled with compact discs, DVDs, and tapes, with a lazy couch and a huge flat-screen TV. The study has a computer with wireless access. Outside, my remote control opens and closes the garage, which has two late-model cars, tools, shoes, and boxes of stuff. Summer and winter clothes are packed tightly and neatly in several closets. There are bags and shoes, toys, bedspreads and towels, underwear and toiletries for each one of us. In short, we have just about everything that an average American household has, and a whole lot more.

Our days are consumed by routines and discoveries, by traffic and tire chains, by food and entertainment. It's such a good life in America that I can almost forget the swarms of flies on dead bodies or the boy soldiers who attempted to murder me near the shores of Tonle Sap Lake, when I was barely fifteen.
\end{abstract}




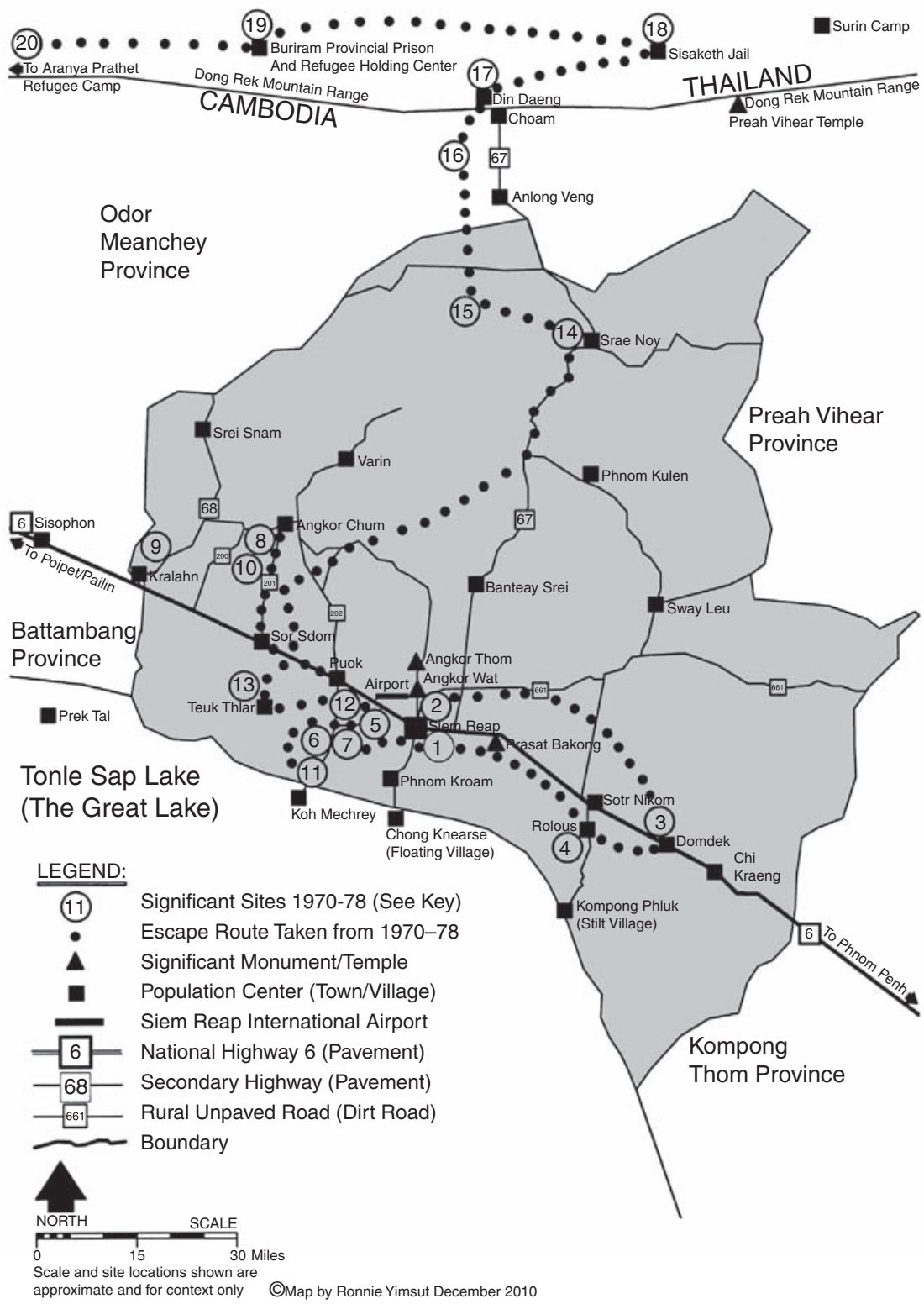

Siem Reap Province, Kingdom of Cambodia 


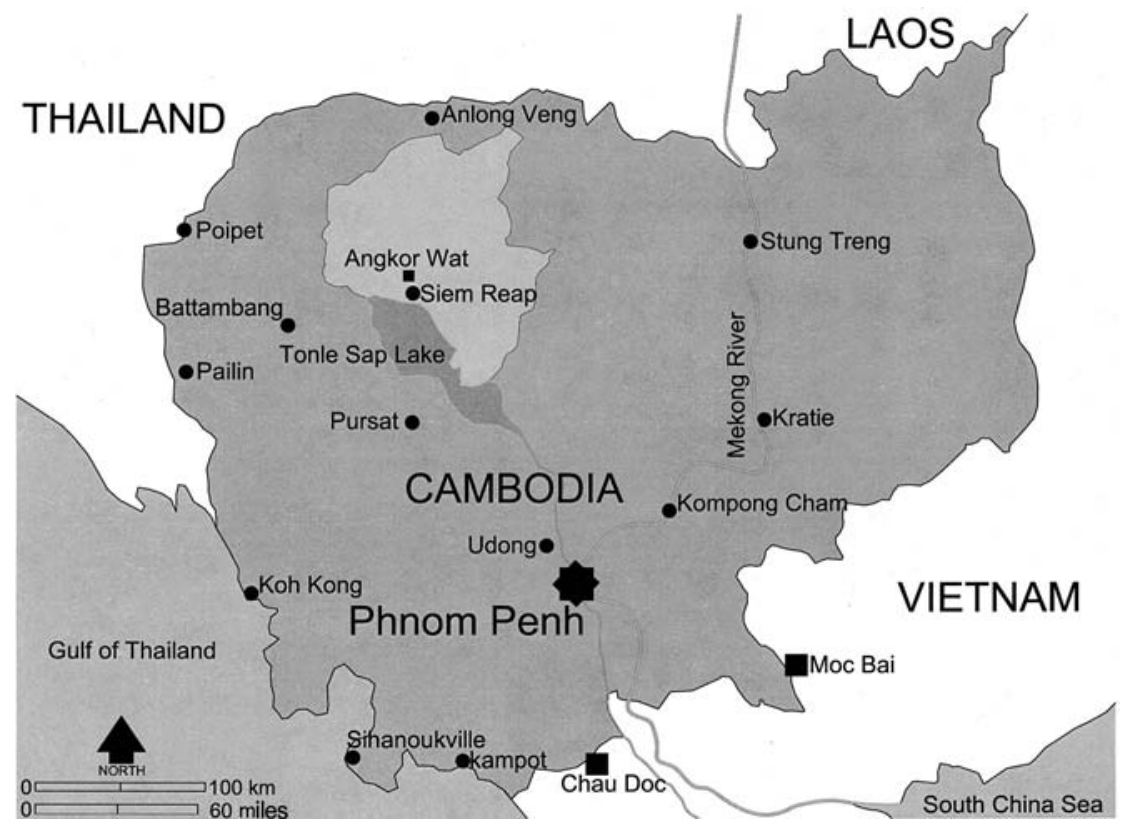

Cambodia Context Map

KEY: Significant Sites in Cambodia (I970 to 1978)

No. Name

I Wat Damnak

2 Sala Komrou

3 Domdek

4 Rolous

5 Krobey Riel

6 Keo Poeur

$7 \quad$ Kok Poh and Kork Putrea

8 Tapang

9 Kralahn

Io Wat Yieng

II Ta Source Hill

I2 Dorn Swar

I3 Prey Roniem

I4 Srae Noy

I5 Resin Mountain

I6 Deep Northern Jungle

I7 Din Daeng Village

I8 Sisaketh Jail

I9 Buriram Provincial Prison and Refugee Holding Center

20 Aranya Prathet Refugee Camp 
For many years I denied my memories. In pursuit of the great American dream, I pushed away the haunting nightmares of the Khmer Rouge and I ignored those soft images of family now lost. Instead of examining my roots, I pressed ahead.

Eventually I invited the memories back in. My fear of the terrifying images was overridden by the drive to revisit my past, Cambodia's past. I decided that I must give voice to my intimate witness to the tragedies, to the genocidal images burned into my mind. Even harder, I had to go back and recall the sweet innocence of my family experiences before the war.

I remembered with fondness my childhood in Siem Reap, an agricultural town near the famous Angkor Wat temples and the Tonle Sap Lake. I learned to read and write at Wat Damnak, later going to Sala Komrou. I was only nine when war forced Siem Reap's citizens into the Angkor Wat temples for shelter.

Shortly after the Khmer Rouge's takeover of our town, I was in Krobey Riel, a few miles away. Angkar began to rule our lives. Over the years we were forced to relocate to the flood plains of Keo Poeur, the village of Kork Putrea, and the remote town known as Tapang. I worked on a massive canal at Ta Source Hill, not far from Tonle Sap Lake.

My escape at age fifteen took me from a haystack in Dorn Swar to the flooded forests of Prey Roniem; from huge trees on Resin Mountain to the deep northern jungle. My group and I finally ascended the Dong Rek Mountain Range to reach Thailand.

For being refugees, we were sent to Sisaket Provincial Jail, Buriram Provincial Prison, and then the holding center. Eventually we found our way to the Aranyaprathet Refugee Camp, from which I immigrated to the United States. I was not quite sixteen. I lived with my cousins in Washington, D.C., before moving to Seattle, Washington; Beaverton, Oregon; and then Eugene, Oregon. It was especially during this time that I excelled at blocking out my memories. You see, for fourteen years, I foolishly tried to ignore and hide from my past. I lived in tremendous physical pain and emotional suffering. Nightmares so tormented me that, at one time or another, I contemplated suicide as an easy way out. Fortunately, I could not muster enough courage.

Some people ask how I remembered so much detail. I started writing about my experiences in the refugee camp and I continued writing after I arrived in America. In revisiting my old recorded memories and writing this book, I ripped open old wounds that never really healed. It was terrible, so horrible of a torture to write out my memories. What kept me going was knowing that I had to express memories or die. Soon after I wrote the first paragraphs, the dam broke. I cried, reliving memories of good and bad times. For days, I couldn't sleep. I cried myself to sleep and woke up shivering, in tears. The anguish and pain were as real as the day they happened. Even as I write these words, that long-ago event feels like yesterday. 
Over the next several years I found ways to cope. I faced issues that shaped me. I spoke out and wrote to people. The more I shared my pain, the better I felt. I encouraged others to confront their own pasts. I dared them.

I went to Cambodia where my tragic story began. I wanted the story to end there, where it all began . . . not so long ago. I refused to shut up and I also refused to give up.

The book you hold in your hands details memories forged at a time of great upheaval and crisis. My story is also a call for justice, and as such it is shaped and informed by the present situation in Cambodia. I have done my best to accurately capture the details of my experiences and confirm historical facts, and I am grateful to those who have helped me focus and occasionally correct my account. If errors exist they are mine and mine alone. I stand behind the truth of the events and memories. I hope that if I've made any mistakes, they will be forgiven.

Of course, everyone views events in unique ways, and I know that others will have their own tales to tell. Most of my family members perished during the Khmer Rouge era; my hope is that this story accounts for some of their lived sorrows and joys. Other Cambodians survived and migrated to America, each with his or her own stories to pass on. Surely these collective tales will add up to the truth of the Cambodian-American journey.

That is what I want.

This is who I am. This is a tale from a modern-day genocide survivor.

Ronnie Yimsut Milwaukee, Wisconsin, February 2OII 
